\title{
PEMANFAATAN TEPUNG KULIT BUAH MARKISA (Passiflora edulis var. edulis) FERMENTASI Phanerochaete chrysosporium DALAM RANSUM BENTUK PELET TERHADAP PERFORMANS KELINCI REX JANTAN LEPAS SAPIH
}

\section{The Utilization of Passiflora Edulis Var.Edulis Fermented by Phanerochaete Chrysosporium in Pellet Diet on Performances of Weaning Male Rex Rabbits}

\author{
Maeika Putri Sitepu ${ }^{1}$, Tri Hesti Wahyuni ${ }^{2}$, dan Nevy Diana Hanafi ${ }^{2}$
}

1. Mahasiswa Program Studi Peternakan Fakultas Pertanian Universitas Sumatera Utara

2. Staf Pengajar Program Studi Peternakan Fakultas Pertanian Universitas Sumatera Utara

\begin{abstract}
The passiflora edulis is a waste of passion fruit pell that can be used in pellet diet. This study aimed to determine the effect of fermentation passiflora edulis by Phanerochaete chrysosporium in Pellet Diet on Performances of Weaning Male Rex Rabbits. The design experiment used completely randomized design (CRD) with 4 treatments and 5 replications. The treatments were level of $P_{0}(0 \%), P_{1}(10 \%), P_{2}(20 \%)$ and $P_{3}(30 \%)$. The result of this research indicates that the average of feed intake (g/head/day); 71.07; 69.34; 71.18 and 71.28 , respectively, while the average daily gain $(A D G) ; 14.96 ; 17.00 ; 17.04$ and 17.36, respectively, and Feed convertion ratio $(F C R) ; 4,78 ; 4,28 ; 4,28$ dan 4,03, respectively. The results statistical analysis indicates that the utilization of fermented passiflora edulis in diet gaves not significantly different $(P>0.05)$ on performance of weaning male rex rabbit. The conclusion of this research that the utilization of fermented and non fermented passiflora edulis can be use alternative feed ingredients until $30 \%$ on diet for weaning male rex rabbits.
\end{abstract}

Keywords : Passiflora edulis, Fermentation, Phanerochaete chrysosporium, Pellet, Performance, Male Rex Rabbit.

\begin{abstract}
ABSTRAK
Kulit buah markisa merupakan limbah dari buah markisa yang dapat dimanfaatkan sebagai pakan ternak dalam ransum bentuk pelet. Penelitian ini bertujuan untuk melihat pengaruh dari pemanfaatan tepung kulit buah markisa (KBM) fermentasi Phanerochaete chrysosporium dalam ransum bentuk pelet terhadap performans kelinci rex jantan lepas sapih. Rancangan yang digunakan dalam penelitian ini adalah rancangan acak lengkap (RAL) dengan 4 perlakuan dan 5 ulangan. Perlakuan terdiri dari berbagai level yaitu $\mathrm{P}_{0}(0 \%) ; \mathrm{P}_{1}$ $(10 \%) ; \quad \mathrm{P}_{2}(20 \%)$ dan $\mathrm{P}_{3}(30 \%)$. Hasil penelitian menunjukan rataan konsumsi (g/ekor/hari) $(71.07 ; 69.34 ; 71.18 ; 71.28)$, pertambahan bobot badan $(14.96 ; 17.00 ; 17.04 ; 17.36)$, konversi ransum sebesar $(4.78 ; 4.28 ; 4.28 ; 4.03)$. Hasil analisis ragam menunjukan bahwa perlakuan tidak memberikan pengaruh berbeda nyata $(\mathrm{P}>0.05)$ terhadap konsumsi ransum, pertambahan bobot badan dan konversi ransum. Kesimpulannya adalah penggunaan tepung kulit buah markisa fermentasi dan tanpa fermentasi dapat digunakan sebagai pakan alternatif sampai level $30 \%$ dalam ransum kelinci rex jantan.
\end{abstract}

Kata kunci : Kulit Buah Markisa, Fermentasi, Phanerochaete chrysosporium, Pelet, Performans, Kelinci Rex Jantan.

\section{PENDAHULUAN}

Di Indonesia produksi jus markisa sampai dewasa ini terlihat cukup banyak, ini sejalan dengan permintaan dan perkembangan industri pengolah (pabrik markisa). Dalam pengolahan buah markisa menjadi jus (sari) pada pabrik markisa bagian yang tidak diolah berupa kulit buah markisa (KBM) sebanyak 2,5-4 ton per hari. Sumatera Utara terkhususnya 
di Berastagi merupakan salah satu daerah sentral produksi markisa (Passiflora edulis). Dari buah markisa terdapat sari buah sebanyak 40,69\% selebihnya adalah kulit buah sebanyak $44,53 \%$ dan biji sebanyak $14,78 \%$. Ketersediaan kulit buah markisa tidak bersifat musiman sehingga dapat diperoleh setiap waktu.

Pakan yang sempurna berarti cukup mengandung zat makanan yang dibutuhkan kelinci terdiri dari protein, karbohidrat, lemak, mineral, vitamin dan air sehingga pakan yang sempurna mampu mengembangkan pekerjaan sel tubuh untuk proses-proses pertumbuhan (Hartadi et al., 1997). Kulit buah markisa sangat potensial untuk digunakan sebagai pakan ternak kelinci. Untuk itu perlu dilakukan alternatif dalam pemanfaatan limbah pertanian sebagai pakan ternak untuk meningkatkan nilai tambah bagi peternak kelinci. Produksi limbah kulit buah markisa apabila tidak dikendalikan akan menjadi sumber polusi udara atau air yang dapat mempengaruhi kesehatan masyarakat yang tinggal disekitar pabrik.

Secara fisik kulit buah markisa relatif tebal dan cukup keras karena itu perlu diubah menjadi tepung. Sementara itu pemanfaatnya juga belum optimal dan terbatas untuk pakan ternak karena mempunyai kendala yaitu kandungan serat kasar yang tinggi berupa lignin $(30,16 \%)$ dan zat anti nutrisi berupa tannin $(1,85 \%)$. Salah satu cara mengatasinya adalah dengan melakukan fermentasi dengan menggunakan jamur Phanerochaete chrysosporium sebagai fermentor untuk membantu mengoptimalkan kerja mikroorganisme di saluran pencernaan.

Pakan yang diberikan pada ternak kelinci sebaiknya berbentuk pelet komplit. Pelet merupakan bentuk bahan pakan yang dipadatkan sedemikian rupa dari bahan konsentrat atau hijauan dengan tujuan untuk mengurangi sifat keambaan pakan. Pakan dalam bentuk pelet lebih disukai ternak dibandingkan pakan berbentuk tepung. Menurut Behnke (2001), pemberian pakan bentuk pelet dapat meningkatkan performa dan konversi pakan ternak bila dibandingkan dengan pakan bentuk mash Pakan berbentuk pelet mengurangi pemborosan ransum akibat tumpah/terbuang, selain itu ternak tidak dapat memilih pakan yang disukai atau tidak disukai karena keseluruhan bahan pakan telah menyatu dalam bentuk pelet.

Adapun tujuan dari penelitian ini adalah Pemanfaatan kulit buah markisa yang difermentasi dengan Phanerochaete chrysosporium dalam ransum bentuk pelet dapat dijadikan sebagai pakan alternatif yang mampu meningkatkan performans (konsumsi pakan, pertambahan bobot badan dan konversi pakan) kelinci rex jantan lepas sapih. 


\title{
BAHAN DAN METODE PENELITIAN
}

\section{Lokasi dan Waktu Penelitian}

Penelitian dilaksanakan di Jl. Udara Gg. Rukun (Peternakan Kelinci Rukun Farm) Berastagi, Kabupaten Karo. Penelitian ini berlangsung selama 3 bulan.

\section{Bahan dan Alat Penelitian}

\section{Bahan}

Bahan yang digunakan yaitu kelinci rex jantan lepas sapih 20 ekor dengan rata-rata bobot badan $918 \pm 75,18 \mathrm{~g}$. Bahan pakan yang terdiri dari tepung kulit buah markisa, tepung jagung, dedak padi, bungkil kedelai, tepung ikan, top mix dan molases. Tepung kulit buah markisa (KBM) difermentasi dengan jamur Phanerochaete chrysosporium kemudian bahan pakan diolah menjadi pakan berbentuk pelet. Daun wortel dan obat-obatan seperti Permentyhl 5\%, Pyroxy dan vitamin B-complex serta rodalon.

\begin{abstract}
Alat
Alat yang digunakan yaitu kandang individu sebanyak 20 petak, timbangan kapasitas $5 \mathrm{~kg}$ untuk menimbang kelinci, pakan dan sisa pakan, tempat pakan pada tiap kandang dengan total sebanyak 20 unit, mesin giling, mesin pencetak pelet, autoclave, oven, termometer, alat pembersih kandang, kantong plastik.
\end{abstract}

\section{Metode Penelitian}

Metode penelitian yang digunakan adalah rancangan acak lengkap (RAL) dengan 4 perlakuan dan 5 ulangan. Adapun perlakuan yang diteliti adalah sebagai berikut:

P0 : Ransum dengan penambahan 30\% KBM tanpa fermentasi dan 0\% KBM fermentasi Phanerochaete chrysosporium

P1 : Ransum dengan penambahan 20\% KBM tanpa fermentasi dan 10\% KBM fermentasi Phanerochaete chrysosporium

P2 : Ransum dengan penambahan 10\% KBM tanpa fermentasi dan 20\% KBM fermentasi Phanerochaete chrysosporium

P3 : Ransum dengan penambahan 0\% KBM tanpa fermentasi dan 30\% KBM fermentasi Phanerochaete chrysosporium 
Model matematik percobaan yang digunakan adalah Rancangan Acak Lengkap :

Yij $\quad=\boldsymbol{\mu}+\boldsymbol{\sigma} \mathbf{i}+\sum \mathbf{i j}$

Keterangan :

Yij = Nilai pengamatan yang diperoleh dari satuan percobaan dari perlakuan ke-i dan ulangan ke-j

$\boldsymbol{\mu}=$ Nilai tengah umum

$\boldsymbol{\sigma i}=$ Efek dari perlakuan ke-i

$\sum \mathbf{i j}=$ Pengaruh galat percobaan perlakuan ke-i dan ulangan ke-j

Tabel 1. Kandungan Nutrisi Maasing-Masing Bahan Pakan:

\begin{tabular}{llcccc}
\hline No & \multicolumn{1}{c}{ Bahan Pakan } & $\begin{array}{c}\text { PK } \\
(\%)\end{array}$ & $\begin{array}{c}\text { EM } \\
(\mathrm{kkal} / \mathrm{mg})\end{array}$ & $\begin{array}{c}\text { SK } \\
(\%)\end{array}$ & $\begin{array}{c}\text { LK } \\
(\%)\end{array}$ \\
\hline 1. & Kulit Buah Markisa (KBM)* & 8,53 & 3575 & 39,56 & 0,6 \\
2. & Kulit Buah Markisa fermentasi* & 18,56 & 3615 & 34,96 & 1,39 \\
3. & Tepung Jagung** & 8,6 & 3370 & 4,3 & 6,9 \\
4. & Dedak Padi** & 8,5 & 1890 & 13 & 4,2 \\
5. & Bungkil Kedelai** & 41,3 & 2240 & 5,3 & 4,9 \\
6. & Tepung Ikan*** & 55 & 2565 & 1 & 10 \\
7. & Top Mix & 0 & 0 & 0 & 0 \\
8. & Molases*** & 3,8 & 1020 & 0.38 & 0.08 \\
\hline
\end{tabular}

Sumber: * Laboratorium Loka Penelitian Kambing Potong (2015)

** NRC (1984)

*** Laboratorium Ilmu Nutrisi Dan Pakan Ternak (2015)

Tabel 2. Formulasi Ransum Dan Kandungan Nutrisi Ransum

\begin{tabular}{clcccc}
\hline \multirow{2}{*}{ No } & \multirow{2}{*}{ Bahan Pakan } & \multicolumn{4}{c}{ Perlakuan } \\
\cline { 3 - 6 } & & P0 & P1 & P2 & P3 \\
\hline 1. & Kulit Buah Markisa & 30 & 20 & 10 & 0 \\
2. & Kulit Buah Markisa fermentasi & 0 & 10 & 20 & 30 \\
3. & Tepung Jagung & 30 & 30 & 30 & 30 \\
4. & Dedak Padi & 11 & 11 & 11 & 11 \\
5. & Bungkil Kedelai & 14 & 14 & 14 & 14 \\
6. & Tepung Ikan & 7 & 7 & 7 & 7 \\
8. & Top Mix & 2 & 2 & 2 & 2 \\
9. & Molases & 6 & 6 & 6 & 6 \\
\hline Total & & 100 & 100 & 100 & 100 \\
\hline Kandungan Nutrisi & 15,93 & 16,94 & 17,94 & 19,27 \\
\hline 1. & PK $(\%)$ & 2845,75 & 2849,5 & 2853,5 & 2857,75 \\
2. & EM $(k k a 1 / k g)$ & 15,42 & 14,96 & 14,50 & 14,04 \\
3. & SK $(\%)$ & 4,10 & 4,18 & 4,26 & 4,34 \\
4. & LK $(\%)$ & \multicolumn{3}{c}{} \\
\hline
\end{tabular}

Sumber: Hasil perhitungan dari Tabel 1 


\section{Parameter Penelitian}

\section{a. Konsumsi Ransum}

Konsumsi ransum dihitung dengan cara menimbang jumlah pakan yang diberikan dikurangi dengan sisa pakan selama penelitian yang dinyatakan dalam g/ekor/hari dalam bentuk bahan kering (BK). Konsumsi ransum dipengaruhi oleh kesehatan ternak, palatabilitas, mutu ransum dan tata cara pemberian Konsumsi $=$ Pakan yang diberikan pakan sisa (g/ekor/hari) (Anggorodi, 1995).

\section{b. Pertambahan Bobot Badan}

Pertambahan bobot badan harian merupakan selisih antara bobot badan awal dengan bobot badan akhir dibagi dengan lama pemeliharaan dinyatakan dalam g/ekor/minggu (Tillman et al,, 1998).

$$
\text { PBBH }=\frac{\text { bobot akhir }- \text { bobot awal }}{\text { Waktu (minggu) }}
$$

\section{c. Konversi Ransum}

Konversi pakan merupakan perbandingan antara jumlah konsumsi pakan dengan pertambahan bobot badan harian selama pemeliharaan (Deblass dan Wiseman, 1998).

Konversi pakan $=\underline{\text { Konsumsi }(\mathrm{g} / \mathrm{hari})}$

PBB

\section{HASIL DAN PEMBAHASAN}

Hasil nilai rataan terhadap konsumsi ransum, pertambahan bobot badan dan konversi ransum kelinci rex jantan lepas sapih dapat dilihat pada Tabel 3 dibawah ini.

Tabel 3. Rataan konsumsi ransum, pertambahan bobot badan dan konversi ransum kelinci rex jantan lepas sapih

\begin{tabular}{cccc}
\hline \multirow{3}{*}{ Perlakuan } & \multicolumn{3}{c}{ Rataan Parameter } \\
\cline { 2 - 4 } & $\begin{array}{c}\text { Konsumsi Pakan } \\
\text { (g/ekor/hari) }\end{array}$ & $\begin{array}{c}\text { PBB } \\
\text { (g/ekor/hari) }\end{array}$ & $\begin{array}{c}\text { Konversi Pakan } \\
\text { (g/ekor/hari) }\end{array}$ \\
\hline P0 & $71,05^{\text {tn }}$ & $14,96^{\text {tn }}$ & $4,78^{\text {tn }}$ \\
P1 & $69,34^{\text {tn }}$ & $17,00^{\text {tn }}$ & $4,28^{\text {tn }}$ \\
P2 & $71,18^{\text {tn }}$ & $17,04^{\text {tn }}$ & $4,28^{\text {tn }}$ \\
P3 & $71,28^{\text {tn }}$ & $17,36^{\text {tn }}$ & $4,03^{\text {tn }}$ \\
\hline
\end{tabular}

Ket $:$ tn $=$ tidak nyata 


\section{Konsumsi Ransum}

Konsumsi ransum adalah kemampuan untuk menghabiskan sejumlah ransum yang diberikan. Konsumsi ransum dapat dihitung dengan pengurangan jumlah ransum yang diberikan dengan sisa dan hamburan.

Tabel 3 menunjukkan bahwa total rataan konsumsi bahan kering ransum hasil penelitian sebesar 70.71 g/ekor/hari. Hasil analisis ragam menunjukkan hasil yang tidak berbeda nyata $(\mathrm{P}>0,05)$ yang berarti bahwa penggunaan kulit buah markisa yang difermentasi sampai $30 \%$ dari total ransum tidak berpengaruh terhadap konsumsi bahan kering ransum kelinci rex lepas sapih. Hal tersebut diduga terjadi karena kisaran kandungan nutrien bahan pakan dari setiap perlakuan memiliki nilai nutrisi hampir sama mengakibatkan tingkat konsumsi yang sama. Tingkat palabilitas juga diduga memiliki respon yang sama sehingga menyebabkan tingkat konsumsi pakan fermentasi dan non fermentasi sama-sama disukai oleh ternak. Hal ini sesuai dengan pernyataan Parakkasi (1999), menyatakan bahwa tinggi rendahnya konsumsi pakan dipengaruhi oleh palatabilitas (rasa dan tekstur pakan).

Rataan konsumsi ransum hasil penelitian lebih baik dibandingkan hasil penelitian Magdalena (2014) yang menggunakan pod kakao fermentasi dengan bioaktifator local (MOL) pada kelinci rex lepas sapih yaitu 49,51 g/ekor/hari. Menurut hasil penelitian Aritonang (2004) yang menggunakan objek kelinci anakan jenis rex diberi ransum dengan beberapa level kandungan protein dan energy biovet diperoleh konsumsi ransum antar perlakuan berkisar antara 202,96 g/minggu hingga 244,46 g/minggu dengan rataan 222,46 g/minggu atau $32 \mathrm{~g} /$ hari. Hal ini disebabkan karena aroma tepung kulit buah markisa disukai oleh ternak, sehingga pakan yang diberikan dapat dikonsumsi dalam jumlah yang banyak.

Jumlah konsumsi ransum merupakan faktor penentu yang paling penting untuk menentukan jumlah nutrien yang didapat oleh ternak dan selanjutnya mempengaruhi tingkat produksi. Konsumsi ransum dipengaruhi oleh kondisi ternak itu sendiri dan kondisi lingkungan pada saat pemeliharaan. Hal ini sesuai dengan pernyataan Kartadisastra (1994) yang menyatakan bahwa tinggi rendahnya konsumsi pakan dipengaruhi oleh faktor eksternal yaitu lingkungan dan faktor internal atau kondisi ternak sendiri yang meliputi temperatur lingkungan, palatabilitas, status fisiologi yaitu umur, jenis kelamin dan kondisi tubuh, konsentrasi nutrien, bentuk pakan, bobot tubuh dan produksi.

\section{Pertambahan Bobot Badan (PBB)}

Pertambahan bobot badan dapat diketahui berdasarkan selisih antara penimbangan bobot akhir dengan penimbangan bobot badan awal yang dihitung setiap minggu. Data hasil 
pertambahan bobot badan selama penelitian ini dapat dilihat pada Tabel 3. Tabel 3 menunjukkan bahwa perlakuan memberikan pengaruh yang tidak nyata $(\mathrm{P}>0,05)$ terhadap pertambahan bobot badan. Total rataan pertambahan bobot badan hasil penelitian sebesar 16,59 g/ekor/hari. Hal ini menunjukkan bahwa pengaruh pemberian kulit buah markisa fermentasi dan non fermentasi yang dicampur dalam ransum berbentuk pelet menunjukkan hasil yang tidak berbeda nyata terhadap pertambahan bobot badan kelinci rex jantan lepas sapih.

Menurut Rasyid (2009) salah satu faktor yang mempengaruhi pertambahan bobot badan adalah konsumsi pakan. Konsumsi pakan dan kecernaan pakan yang tinggi akan menghasilkan pertambahan bobot badan yang lebih tinggi. Hal ini disebabkan oleh semakin banyak nutrient yang diserap oleh tubuh ternak ters Jurnal Peternakan Integratif Vol.4 buah markisa fermentasi cendrung memiliki nilai pertambanan bobot badan harıan yang tıdak berbeda nyata dengan kulit buah markisa tanpa fermentasi. Hal ini terjadi diduga karena terdapatnya kandungan zat anti nutrisi berupa tanin pada kulit buah markisa. Tanin dapat mempengaruhi kecernaan suatu bahan pakan. (Makkar, 1993) menyatakan bahwa tanin dapat mengikat protein dan membentuk senyawa taninprotein yang tidak terdegradasi oleh saluran pencernaan ternak. Menurut Padang (2004) bahwa nutrien yang paling penting bagi ternak untuk pembentukan sel-sel baru dan pembesaran ukuran sel sebagai penyebab pertambahan bobot badan adalah protein.

Pertambahan berat badan kelinci yang ideal sebesar 4 - 21 gram/ekor/hari (Sangare, et al., 1992). Pertambahan bobot badan kelinci pada penelitian (16,59 g/ekor/hari) cukup baik untuk kelinci jenis rex, karena lebih tinggi bila dibandingkan dengan hasil penelitian Leslie (2014) dengan memanfatkan kulit pisang raja difermentasi dengan MOL dan Trichoderma harzianum pada kelinci rex yaitu sebesar 11,73 g/ekor/hari.

\section{Konversi Ransum}

Konversi ransum pada penelitian ini dihitung dalam bentuk bahan kering dengan cara membandingkan banyak jumlah pakan yang dikonsumsi dengan pertambahan bobot badan yang dicapai setiap minggu. Rataan konversi ransum selama penelitian dapat dilihat pada Tabel 3. Pada tabel menunjukkan bahwa perlakuan memberikan pengaruh yang tidak nyata $(\mathrm{P}>0,05)$ terhadap konversi pakan. Total rataan konversi pakan hasil penelitian sebesar 16,59 g/ekor/hari.

Hasil yang tidak berbeda nyata sejalan dengan nilai konsumsi pakan dan pertambahan bobot badan yang tidak berbeda nyata juga karena konversi ransum merupakan perbandingan 
antara jumlah konsumsi pakan dengan pertambahan bobot badan pada satuan yang sama. Hal ini sesuai dengan pendapat Champbell dan Lasley (1985) mengatakan bahwa faktor-faktor yang mempengaruhi konversi ransum adalah genetik, umur, berat badan, tingkat konsumsi ransum, pertambahan bobot badan, palatabilas dan hormon.

Konversi ransum memberikan penilaian terhadap efisiensi penggunaan ransum oleh kelinci. Pada nilai konversi ransum yang diperoleh menunjukkan bahwa kulit buah markisa fermentasi dapat menurunkan nilai konversi ransum. Deblass dan Wiseman (1998) menyatakan bahwa semakin tinggi konsumsi pakannya menyebabkan pertambahan bobot hariannya menjadi tinggi sehingga nilai konversi pakannya menurun. Semakin kecil nilai konversi pakan menunjukkan semakin sedikitnya pakan yang dibutuhkan untuk menghasilkan per gram bobot badan.

Hasil dari penelitian ini memiliki nilai konversi yang lebih kecil dibandingan dengan hasil penelitian Magdalena (2014) yang menggunakan pod kakao fermentasi dalam ransum kelinci rex yaitu sebesar 5,66. Hal ini disebabkan karena kecernaan pada bahan pakan kulit buah markisa lebih mudah dicerna dibandingkan dengan pod kakao fermentasi.

Menurut Rasyaf (1996), konversi pakan digunakan sebagai pegangan berproduksi karena melibatkan bobot badan dan konsumsi pakan. Menilai pakan dan kualitas pakan yang lebih baik adalah dengan melihat pertumbuhan dan pertambahan bobot badan ternak. Pertambahan bobot badan inilah yang mencerminkan bagaimana protein dan keseimbangan asam amino yang ada di dalam pakan yang diberikan memberikan dampak positif bagi ternak.

\section{KESIMPULAN}

Penggunaan tepung kulit buah markisa (Passiflora edulis var.edulis) fermentasi dan tanpa fermentasi Phanerochaete chrysosporium dapat digunakan sebagai pakan alternatif dalam ransum bentuk pelet sampai pada level 30\% pada kelinci rex jantan lepas sapih.

\section{DAFTAR PUSTAKA}

Anggorodi. 1995. Nutrisi Aneka Ternak Umum. PT. Gramedia Pustaka Utama. Jakarta.

Aritonang. 2004. Penngaruh Penambahan Biovet Dalam Ransum Dengan Berbagai Kandungan Protein-Energi Terhadap Pertumbuhan Anak Kelinci Rex. Institup Pertanian Bogor-Press. Bogor. 
Behnke, K. C. 2001. Processing Factors Influencing Pelet Quality. Feed Tech. 5 (4): 1-7. Disitasi Skripsi Rizqiani, A. 2011. Performa Kelinci Potong Jantan Lokal Peranakan New Zeland White Yang Diberi Pakan Silase Atau Pelet Ransum Komplit. Institup Pertanian Bogor-Press. Bogor.

Champbell, J. R. and J.F. Lasley. 1985. The Science of Animals that Sarved Mankid. 3th. Tata Mc Graw. Hill Publishing Company Limited New Delhi. Pp 390-392.

Deblass, C. and J. Wiseman. 1998. The Nutrition of The Rabbit. CABI Publishing. New York, USA. Skripsi. Risqiani, A. 1998. Performa Kelinci Potong Jantan Lokal Peranakan New Zeland White yang Diberi Pakan Silase atau Pelet Ransum Komplit. Institup Pertanian Bogor-Press. Bogor.

Kartadisastra, H.R. 1994. Komposisi Kandungan Bahan Penyusun Ransum. Kanisius. Yogyakarta.

Leslie. 2014. Pemanfatan Kulit Pisang Raja Difermentasi Dengan Mol Dan trichoderma horzianum Pada Berbagai Ransum Terhadap Performans Kelinci Rex Jantan Lepas Sapih. USU-Pres. Medan.

Magdalena. 2014. Subtitusi Dedak Padi Dengan Daging Buah Kakao Fermentasi Dalam Ransum Pellet Terhadap Performans Kelinci Rex Jantan Lepas Sapih. USU-Pres. Medan.

Makkar, H.P.S. 1993. Antinutritional Factors In Foods For Livestock. Brit. Soc. Anim. Prod. 16: 69-85.

NRC. 1984. Nutrient Requirement for the Domestic Animals. Rabbits. 8th ed. NAS. Washington, DC.

Padang, 2004. Performa Produksi Domba Lokal yang diberi Cairan Rumen Kambing. Jurnal Agroland 11 (1): 78-83

Parakkasi, A., 1999. Ilmu Nutrisi Dan Makanan Ternak Ruminansia. Universitas Indonesia Press. Jakarta.

Rasyaf, M., 1996. Pengelolaan Peternakan Unggas Pedaging. Kanisius. Yogyakarta.

Rasyid, H. 2009. Performa produksi kelinci lokal jantan pada pemberian rumput lapang dan berbagai level ampas tahu. Skripsi. Fakultas Peternakan. Institut Pertanian Bogor, Bogor.

Sangare, N., O. M. Ariff, S. Moin and F. Dahlan, 1992. Breed Differences Rabbit. In: Proceeding 2nd Symposium of Malaysia Society of Applied Biology. Selangor. Malaysia.

Tillman AD., H. Hartadi, S. Reksohadiprodjo, S. Prawirokusumo dan S. Lebdosoekojo. 1998. Ilmu Makanan Ternak Dasar. Gadjah Mada University Press. Yogyakarta. 